\title{
CLAYTON CHRISTENSEN EMLÉKÉRE
}

$\mathrm{T}_{\mathrm{t}, \mathrm{s}}^{\mathrm{a}}$ avaly, az év végéhez közeledve kértek fel minket a Rajk Szakkollégium tagjai, hogy meséljünk nekik a Clayton Christensennel, a megszakító innováció kitalálójával töltött néhány közös napunkról. A professzor 2015-ben látogatott el Budapestre a szakkollégium meghívására, hogy átvegye a Herbert Simon-díjat. Mi ekkor két szerepet töltöttünk be - szerkesztettük és írtuk a professzor munkáin alapuló kötetet (Buksa et al., 2015) és mindenhova elkísértük öt, hosszú beszélgetéseket folytatva, fontos gondolatokat el-elcsípve. A decemberben felidézett emlékek még frissek most is, bár sajnos a legszomorúbb okból kell újra elövennünk őket. Clayton Christensen január végén, hosszan tartó betegség után, 67 évesen elhunyt.

Professzor Christensen - vagy ahogy a meghívónkra kapott válaszából megismerhettük: Clay C. - mind a gazdálkodástudomány akadémiai világában, mind az üzleti életben olyan személy volt, akinek a nevével és elméletével szinte mindenki találkozott. Megannyi stratégiai menedzsmenttel foglalkozó könyv, kurzus, módszer és előadás foglalkozott azzal, hogy vajon miként értelmezhető általában és mit is jelenthet egy-egy cég számára az általa leírt „megszakító innováció”. Habár egy gyorsan roppant bonyolulttá tehető elképzelés, a megszakító innováció alapgondolata (Christensen \& Bower, 1996) egyszerüen megfogalmazható: olyan termék vagy szolgáltatás létrehozása, ami nem feltétlenül a „legjobb” a piacon lévő versenytársakhoz képest, mégis kielégíti a sokszor már egyébként „túlszolgált” fogyasztói igényeket, sőt az eddig ki sem szolgált fogyasztók igényeit is, általában a meglévőnél alacsonyabb árszínvonal mellett. Eközben sokszor olyan fogyasztókat elérve, akik ezelőtt nem engedhették meg maguknak, hogy az adott terméket vagy szolgáltatást fogyasszák, tehát új piacot nyitva. Mindezt sok esetben más formában téve, mint az addig megszokott volt. Ezt a fajta innovációt nevezte a professzor megszakító vagy piacteremtő innovációnak.

A piacvezető vállalatok számára a megszakító innováció akkor válik fenyegetéssé, amikor egy termékük (vagy piacuk) eljutott arra a szintre, hogy a fogyasztók már nem hajlandóak többet fizetni egy új funkcióért, egy "jobb" termékért, azaz egy fenntartó (vagy inkrementális) innovációért. Persze ez sokszor már valami olyan funkciót jelent, amire a fogyasztóknak egyébként sincs szüksége („túlszolgálás” jelensége).

A professzor első cikke a témában a vasöntödék átalakuló piacáról szólt a 90-es években, erről Budapesten is beszélt, azonban a megszakító innovációt később számtalan ágazat átalakulását magyarázó elméletté dolgozta tovább. Így alkalmazta a koncepciót például a Wikipedia megjelenésére, ami a kezdetekkor a klasszikus enciklopédiáknál sokkal kevesebb és kevésbé megbízható információt tartalmazott - ám a fogyasztók egy csoportjának ez pont elég volt.

Christensen már a Harvardon megírt PhD-disszertációjában is ezzel a témával foglalkozott. Egy alkalommal elmesélte, hogy akkoriban internet és fejlett keresőrendszerek híján az adatgyüjtési módszere abból állt, hogy minden egyes vasöntödei iparági szaklapot végigolvasott és kijegyzetelt. Persze azt is megjegyezte, hogy a szerencséjére rajta kívül az egyetemen ezek az újságok senkit sem érdekeltek, így „,soha nem kellett értük sorban állni”. Ebből az aprólékos munkából született meg az első, elméletét élö példával alátámasztó írása, és ez a munka alapozta meg a témában elmerülő könyvét is (Christensen, 2013).

A lelkiismeretes munka és a részletekre való odafigyelés jellemző volt rá. Egyik beszélgetésünk során, amikor teljes meglepetésünkre a szakdolgozatainkról érdeklödött, annak fontosságáról beszélt, hogy a kutató ismerje azokat az adatokat, amelyekkel dolgozik. Azaz: hogy honnan jöttek, hogyan és miért keletkeztek. A disszertációjára visszaemlékezve mondta, hogy neki pont ez - a személyes adatgyüjtés - adott lehetőséget és önbizalmat ahhoz, hogy egy új, váratlan mintázatot amit később megszakító innovációnak nevezett el - fedezzen fel és mutasson be.

Christensen elméletét ő maga is sok más területre megpróbálta alkalmazni, kiterjedten foglalkozott az egészségügy (Christensen et al., 2016) és az oktatás megreformálásával is (Christensen et al., 2006; Christensen \& Eyring, 2011). Sokszínüségét mutatja, hogy amikor hozzánk érkezett, azonban egy másik téma foglalkoztatta: a kapitalizmus természete (Christensen \& Bever, 2014). Gondolkodásának egyik kiindulópontja az a kérdés volt, hogy miért vannak hatalmas befektetetlen készpénzállományok amerikai vezető vállalatoknál. Megállapításai mélyrehatóak voltak: a jelenségért a pénzügy "vallását" hibáztatta, azt a menedzsment- és tulajdonosi szemléletet, ami rövid távú célok, gyors megtérülés hajszolására ösztönzi a cégvezetőket. Holott - mondta Christensen - ez a "vallás" egy olyan világban született, ahol az egyik legszűkösebb erőforrás a tőke volt és - mint mondta - ez ma már nem igaz.

Emiatt arra a konklúzióra jutott, hogy a mai befektetésekben az emberi tényező sokkal nagyobb szerepet kellene hogy kapjon, mint a tőke. Erősen hitt abban, hogy az emberekbe kell befektetni és hosszú távú stratégiában kell gondolkodni a bevett pénzügyi mérőszámok háttérbe szorításával (Christensen et al., 2008). Mivel kutatása szerint a gyors megtérülés alapú döntéshozatal ahhoz vezetett, hogy a cégvezetők „,megszakító”, piacteremtő innovációk helyett csak fenntartó vagy hatékonysági innovációkba fektetnek. Ezek az innovációk pedig - mondta - pénzügyi megtérülést képesek termelni, de nem hoznak létre munkahelyeket, nem bővítik a piacokat és a gazdaságot - nem hoznak létre „valójában” újat. Mindezek 
eredményképpen azt vallotta, hogy változásra van szükség - a befektetési gyakorlatban és menedzsmentoktatásban egyaránt. Visszatérve a „vallás” hasonlatához arról írt és beszélt, hogy egyfajta reformációra van szükség - olyanra, ami felteszi azokat a kérdéseket, amikkel az üzleti oktatás és a menedzsmentelmélet visszatalálhat a hosszú távú gazdasági növekedés szolgálatához.

A "vallás" nem volt véletlen metafora, Christensen ugyanis mélyen vallásos volt, a mormon egyház aktív tagja. Valószínüleg ez is erősen hozzájárult ahhoz, hogy mennyire holisztikusan gondolkozott munkáról, világról, üzletröl - és az élet értelméről is. 2010-ben, miután stroke-ot szenvedett el, írta meg “How Will You Measure Your Life?” címü cikkét (Christensen, 2010; később könyv is született belöle Christensen et al., 2012). A cikkben hasonló témákat jár körül, mint a kapitalizmus és a befektetések kapcsán, azonban egy sokkal intimebb témára alkalmazva elképzeléseit - az életre és a személyes sikerre. Központi gondolata egyszerü, de fontos - az életet, a sikert az alapján kell mérni, hogy mire vágyik az ember, hogy miben akar sikeres lenni. Számára ez a család volt, akikre minden tevékenysége előtt és felett szakított időt.

Zseniális előadó volt, igazi szónok. Túlzás nélkül állítható, hogy a Herbert Simon-díj történetének egyik legnagyszerübb előadását tartotta a Magyar Tudományos Akadémia dísztermében. Hangja és szelleme az előadás alatt bejárta a termet, nemcsak elméleteket adott át, de egyfajta életszemléletet is. A Budapesten töltött idő alatt mi, kollégisták megtudtuk, hogy ez az életszemlélet, ez a kedvesség, öszinte érdeklődés és az abbéli hit, hogy a körülötte lévő emberek értékesek, nem csak egy előadás erejéig tart. Így fogunk rá emlékezni, őszinte részvétünket küldve özvegyének, Christine-nek, akire legalább annyi tisztelettel és szeretettel tekintünk, mint Clay-re. Reméljük, hogy a professzor személye és munkássága még sokakat fog hozzánk hasonlóan inspirálni.

A szerzők Prof. Christensen 2015-ös budapesti látogatásának szervezői és a munkái alapján ugyanebben az évben megjelent „Az újdonság megszakító erejével” címü kötet szerkesztői.

\section{Felhasznált irodalom}

Buksa, M., Hoffmann, J., Kiss-Dobronyi, B., \& Thaler, B. (Szerk.) (2015). Az újdonság megszakitó erejével: Összefoglalók Clayton M. Christensen munkásságából (2. kiadás). Budapest: Rajk László Szakkollégium. https://mek.oszk. $\mathrm{hu} / 18600 / 18612$

Christensen, C. M. (2010). How Will You Measure Your Life? Harvard Business Review, July-August, https://hbr. org/2010/07/how-will-you-measure-your-life

Christensen, C. M. (2013). The Innovator's Dilemma: When New Technologies Cause Great Firms to Fail. Cambridge, Mass.: Harvard Business Review Press.

Christensen, C. M., Allworth, J., \& Dillon, K. (2012). How Will You Measure Your Life? New York: Harper Business.

Christensen, C. M., Baumann, H., Ruggles, R., \& Sadtler, T. M. (2006). Disruptive Innovation for Social Change. Harvard Business Review, December. https://hbr.org/2006/12/disruptive-innovation-for-social-change

Christensen, C. M., \& Bever, D. van. (2014). The Capitalist's Dilemma. Harvard Business Review, June. https://hbr. org/2014/06/the-capitalists-dilemma

Christensen, C. M., \& Bower, J. L. (1996). Customer Power, Strategic Investment, and the Failure of Leading Firms. Strategic Management Journal, 17(3), 197-218. JSTOR.

Christensen, C. M., \& Eyring, H. J. (2011). The Innovative University: Changing the DNA of Higher Education from the Inside Out. San Francisco: Jossey-Bass.

Christensen, C. M., Grossman, J., \& Hwang, J. (2016). The Innovator's Prescription: A Disruptive Solution for Health Care. New York: McGraw-Hill Education.

Christensen, C. M., Kaufman, S. P., \& Shih, W. C. (2008). Innovation Killers: How Financial Tools Destroy Your Capacity to Do New Things. Harvard Business Review, January. https://hbr.org/2008/01/innovation-killers-how-financialtools-destroy-your-capacity-to-do-new-things 